12. Coffey PS, Metzler M, Islam Z, Koehlmoos TP 2013, Chlorhexidine for Umbilical Cord Care: Selected Bibliography,BMC Int Health Hum Rights. 2013; 13:44. http://www.ncbi.nlm.nih.gov/pubmed/24139384

13. Groven F M. V, S. M. G. Zwakhalen, Gaby Odekerken-Schröder, E. J. T. Joostenand, J. P. H. Hamers. 2017. How does washing without water perform compared to the traditional bed bath: a systematic review. BMC Geriatr. Published online 2017 Jan 25. doi: 10.1186/s12877-017-0425-4 PMID: $28118815 \quad$ https://www.ncbi.nlm.nih.gov/pmc/articles/ PMC5264342/Hughes RG (ed.)2008. Patient safety and quality: An evidence-based handbook for nurses. (Prepared with support from the Robert Wood Johnson Foundation). AHRQ Publication No. 08-0043. Rockville, MD: Agency for Healthcare Research and Quality.Infections, https://www.cdc.gov/mmwr/preview/mmwrhtml/rr5110a1.htm?vm=r

14. Jordan J. R., Bloom H. L.2010. Prevention of Bacterial Infections in Patients with CIED: Old Traditions Meet New Technology. The Journal of Innovations in Cardiac Rhythm Management. URL: http://www.innovationsincrm.com/cardiac-rhythm-management/2010/october/25-preventionof-bacterial-infections-cied
15. Milstone A. M., Robert A. WeinsteinCatherine L. PassarettiTrish M. Per1Chlorhexidine: Expanding the Armamentarium for Infection Control and Prevention

16. Unahalekhaka A. 2011, Епидемиология на инфекщиите свързани с медицинското обслужване. Глава 3 Епидемиология на инфекциите свързани с медицинското обслужване). URL: http://theific.org/wp-content/uploads/2015/01/Ch-3-Bulgarian.pdf

17. Vasconcelos J.de Melo Buriti, Caliri M. H. Larcher. 2017. Preventing pressure injury in intensive care. Esc. Anna Nery vol.21 no. 1 Rio de Janeiro 2017 Epub Jan 16, 2017. On-line ISSN 2177-9465. http://dx.doi.org/ $10.5935 / 1414-8145.20170001$

18. Webster J, SOsborne. 2015. Preoperative bathing or showering with skin antiseptics to prevent surgical site infection. Cochrane Database Syst Rev. doi: 10.1002/14651858.CD004985.pub5. PubMed PMID: 25927093. URL: https://www.ncbi.nlm.nih.gov/pubmed/25927093

19. WHO guidelines on hand hygiene in health care. 2009. World Health Organization. http://www.who.int/gpsc/5may/tools/9789241597906/en/

\title{
Автори
}

Доц. Деспина Георгиева, дп, Ру „Ангел Кънчев”, ФОЗЗГ, Катедра „Здравни грижи“, dpgeorgieva@uni-ruse, meл: +359 889789100

Профр. Соня Тончева д.оз.н., МУ „Проф. д-р Параскев Стоянов”, Шумен, Катедра „Здравни грижи“, toncheva2960@abv.bg, тел. +359884992535

Доц. Росица Дойновска, ФОЗЗГС, Катедра „Здравни грижи“, doynovska@mail.bg, meл. +3598882221114

Гл. ас. Грета Колева, дузг, РУ „Ангел Кънчев”, ФОЗЗГ, Катедра „Здравни грижи“, gkoleva@uni-ruse, meл: +359882517173

Гл. ас. Иринка Христова, дузг, Ру „Ангел Кънчев” ФОЗ3Г, Катедра „Здравни грижи“, ihristova@uni-ruse, meл: +359 884582733

Гл. ас. д-р Марияна Бачева, ФОЗзГС, Катедра „здравни грижи“, bachewa@abv.bg, mел. 359897963314

\section{ПРОФЕСИОНАЛНИ И СОЦИАЛНИ АСПЕКТИ НА ПРОДЬЛЖИТЕЛНАТА АКУШЕРСКА ГРИЖА}

\author{
T. Евтимова
}

\section{PROFESSIONAL AND SOCIAL ASPECTS OF CONTINUITY OF MIDWIFE RY CARE}

\section{T. Evtimova}

Рез юме. Оказването на продължителна акушерска грижа създава възможност за индивидуален подход при прилагане на добри практики, които са разнообразни по своята същност и поставят важен акиент - пакетът от грижи през иелия иикъл на пренаталния, антенаталния и постнаталния период за жени с нисък риск да бъде осъществяван от акушерка. Настоящата статия представя част от проучване на здравните потребности на жените и нагласата на акушерките за осъществяване на продължителна акушерска грижа.

$S \boldsymbol{m} \boldsymbol{m} \boldsymbol{m}$ a ry. Providing continuity of midwifery care creates an opportunity for an individual approach in the implementation of good practices, which are diverse in nature and put a particular emphasis- the care package throughout the whole cycle of the prenatal, antenatal and postnatal period for women at low risk to be carried out by a midwife. This article presents part of a study on the health needs of women and the attitudes of midwives to the application of continuity of midwifery care.

Key words: continuity of midwifery care, social aspects

\section{Въведение}

В съвременната медицинска практика оказването на здравни грижи все повече утвърждава позитивни модели на живот, позволяващи максимално запазване на физическото, психическото и социалното благополучие на хората.

Акушерският модел на грижи позволява прилагане на концепцията за промоция на здравето чрез създаване на емоционална връзка, атмосфера на доверие и сътрудничество с пациента. Акушерката е професионалист, който притежава знания, умения и има изградено специфично поведение за оказване на самостоятелни грижи, насочени към бременни, родилки, гинекологично болни и здрави жени, признато като автономна акушерска дейност в България с Наредба № 1 от 08.02.2011 г. на Министерството на здравеопазването [3].

\section{Цем}

Целта на настоящото изследване е да се проучат здравните потребностите на жените и нагласата и готовността на акушерките за осъществяване на продължителна акушерска грижа.

\section{Материали и методи}

По отношение на продължителните акушерски грижи основният принцип е, че всяка бременна с неусложнена бременност се нуждае от пренатални, постнатални и патронажни грижи. осъществявани от акушерка. На този принцип са сформирани и двете групи респонденти, основни страни от процеса на продължителна акушерска грижа - акушерки и пациентки. 
Анализирано е мнението на акушерки, работещи в „МБАЛ - АД Шумен“, град Шумен (28), СБАГАЛ „Проф. д-р Димитър Стаматов“ и УМБАЛ „Света Анна“ град Варна (43).

В проведеното проучване взеха участие 313 пациентки, хоспитализирани в родилното отделение в ,МБАЛ - АД Шумен“, град Шумен (145), СБАГАЛ „Проф. Д-р Стаматов“ и УМБАЛ „Света Анна“, град Варна (168).

Проучването е проведено в периода м. септември 2017 - февруари 2018 година.

\section{Резултати и обсъжАане}

В проведеното изследване вземат участие 313 пациентки с цел да се проучат здравните потребностите на жените в периода на бременността, раждането и послеродовия период. Разпределението на пациентките по възраст варира от 18 до 45-годишна възраст, с връх - възрастовия диапазон 18-25 години.

Образованието до известна степен повлиява здравното поведение. Активното търсене на информация по въпроси, свързани с майчинството, е предиктор за натрупване на знания и формиране на правилни здравни навици и поведение.

Анализьт на образователната степен на пациентките показва голям относителен дял на тези със висше $(40.57 \%)$ и средно образование (37.70\%), което е предпоставка за безопасно майчинство и постнатални грижи без риск.

Не бива да се подценява отговорността на жените с по-ниско образование - основно $(17.57 \%)$ и без образование $(4,15 \%)$ (Фигура 1). Тази група е уязвима и от други фактори: нямат трудова заетост, доходите са предимно от социални помощи, здравнонеосигурени са, не посещават женска консултация (ЖК) - кумулиране на фактори, които ги поставят в медикосоциален риск.

Фигура 1. Разпределение на пацииентките по образование

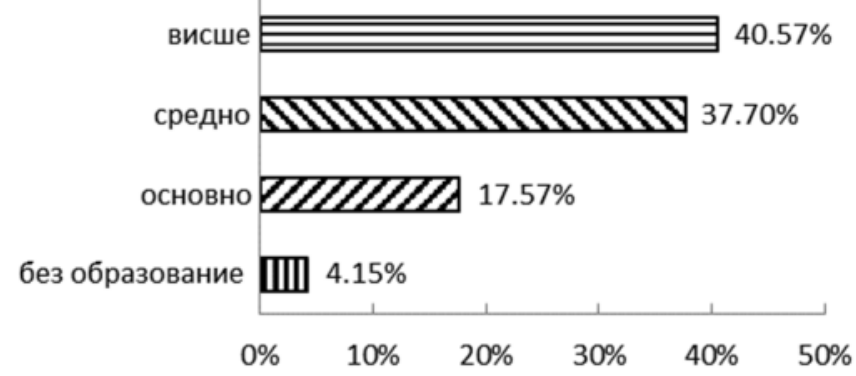

Традиционната консултация, провеждана от акушергинеколог и акушерка по време на бременност посещават малко над половината от анкетираните (62.62\%).

Показателно висок е процентът на анкетираните, за които не са осъществявани здравни грижи от акушерка по време на бременността по различни причини:

- тези, които са посещавали ЖК, провеждана само от акушер-гинеколог (28.11\%);

- бременните, които не са посещавали ЖК (4.47\%), защото са здравно неосигурени - рискови по отношение на своето здраве и на детето си;

- липсата на средства, отдалечеността от градовете и редица други причини затрудняват достьпа на бременните до професионална акушерска грижа. Наблюдението на бременността е предоставено на личен лекар (4.9\%) (Фигура 2).

Пациентките ранжират по значимост очакванията си към акушерката, както следва:

Достыпност - сигурността на пациентката, че може да получи информация, съвет, подкрепа в момент, когато ѝ е необходимо е важно за анкетираните пациентки. Достъпът
Фигура 2. Провеждане на женска консултаџия

не съм посещавала женска консултация 㞏 $4.47 \%$

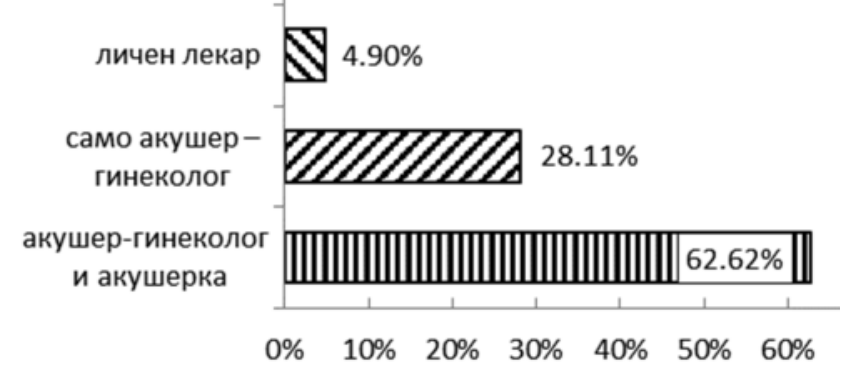

до акушерски грижи на жени от уязвими групи ще допринесе за повишаване на здравната им култура и изграждане на капацитет за отговорно родителство.

Доверие - с акушерката може да се обсъждат не само въпроси, засягащи непосредствено бременността и раждането, но и по-интимни области. Акушерката е длъжна да спазва медицинската тайна с изключение на случаите, в които разказаното може да повлияе на здравето на бъдещата майка и бебе.

Информация и полезни съвети - акушерките са заинтересовани бъдещата майка да бъде активен участник в процеса, а не просто пасивен получател на здравни грижи.

Подкрепа - пренаталната и постнатална психо-емоционална подкрепа на жената и нейното семейство дават възможност на родителите да почувстват увереност в периода на бременността, раждането и грижите за новороденото.

Професионализъм - важно значение за майките е проявата на емпатия и професионална грижа, както и предоставянето на подходяща информация за всички аспекти на грижите, които да им позволят да направят информиран избор. Всяка акушерка е професионалист в предоставянето на акушерски грижи и трябва да определи кога жената има нужда от консултиране с лекар - гинеколог, диетолог, ендокринолог.

Мнението на анкетираните акушерки напълно подкрепя хипотезата за участието им в женска консултация като непълноценно. Посочват и част от причините за този проблем: участието им е формално/административно присъствие $(84.44 \%)$, недостатьчно време за контакт с бременната (80\%), консултациите се провеждат само от лекар (37.77\%). (Фигура 3)

Фигура 3. Участие на акушерката в дейността на женската консултациия

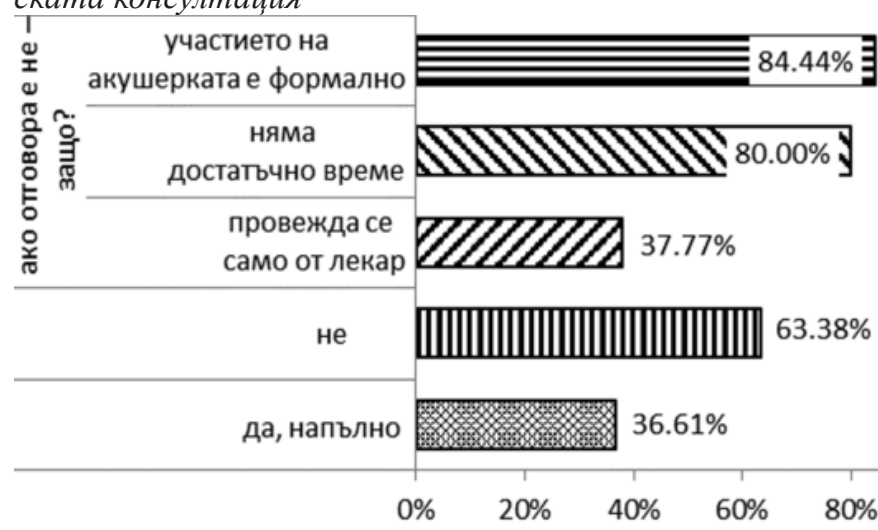

Стратегическата директива на С3О за медицинските сестри и акушерки (Nursing Midwifery Services Strategic Directions 2011-2015) определя активната роля на акушерките и медицинските сестри за гарантирането на това, че здравните 
политики, планове и решения, свързани с професиите им, са специфично ориентирани към потребностите в конкретните страни и са в съответствие с принципите за ефективно управление и регулирана практика. Подчертава се значимостта на акушерките, които заедно с медицинските сестри са найголямата група здравни професионалисти. Посочва се и тяхното място и роля в справянето с предизвикателствата на общественото здраве, осигуряването на непрекъснатост на грижите и зачитане на права̀та на пациентите при променящите се нужди. Начинът, по който се предоставя акушерската грижа, се развива във времето в зависимост от фактори, като демографски и социални промени. През последните години акушерките разширяват своята традиционна роля.

Оценката на акушерките относно притежаваните знания и компетентност за осъществяване на продължителна акушерска грижа е единодушна, че притежават знания и ниво на компетентност (67.60\%). Въпреки това е неизбежно и необходимо за развитието на професията, част от акушерките да искат да задълбочат знанията си и да продължат да развиват своите умения (19.71\%). (Фигура 4)

Фигура 4. Готовност на акушерките за оказване на качествени здравни грижи

в известна степен, необходима ми е и допълнителна подготовка
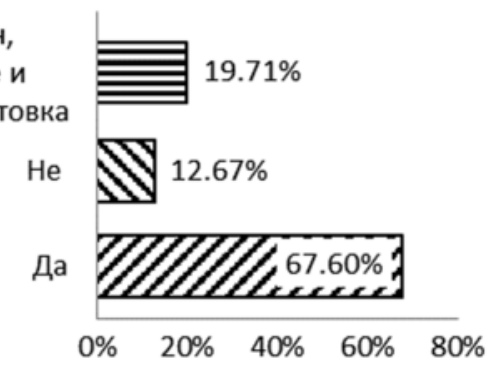

Предпоставките, които ще допринесат автономната продължителна акушерска грижа да стане реалност според анкетираните акушерки са свързани със следните фактори: $(94.37 \%)$;

- въвеждане на Стандарт за акушерски грижи

- законово регламентиране на автономна акушерска дейност (97.18\%); (Фигура 5)

- ясно и точно финансиране на дейността (57.75\%).

Фигура 5. Фактори, предиктор за реализирането на продължителната акушерска грижа в практиката

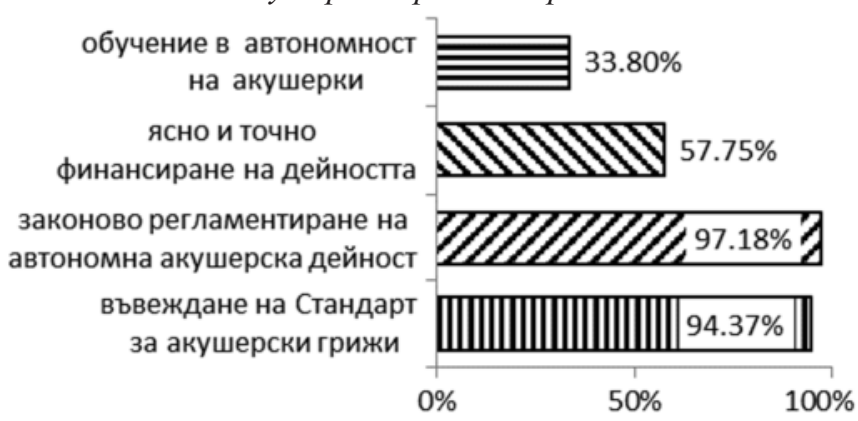

Анализирайки резултатите от проведеното изследване предлагам модел за продължителна акушерска грижа, който може да стане реалност в България след законово регламентиране на автономната акушерска дейност. Бременната ще има възможност да избира "своята“" акушерка - тази, на която има доверие, дава ѝ сигурност, спокойствие и увереност и възможност заедно да извървят пътя към майчинството.

Специфичните особености за начина, по който се управлява продължителната акушерска грижа ще се различават в зависимост от мястото (град или село) и групите от населението (например жени от уязвими групи).

Модельт е динамичен и фокусиран върху жената, като акушерката се адаптира към индивидуалните потребности на всяка жена. Трябва да се създаде среда, която да позволи на бременната да се движи напред спрямо своите очаквания, въпреки несигурността и липсата на опит в майчинството.

Основните принципи, които трябва да бъдат включени в модела за продължителна акушерска грижа, са следните:

- услугите, предоставени по време на майчинството, да бъдат предоставени чрез интегриран модел на акушерски грижи;

- достъпьт на бременните до акушерката да е лесен, желан и осъзнат като необходимост;

- акушерската грижа, получавана от жената трябва да е от една и съща акушерка;

- 24-часова подкрепа от акушерка;

- продължителността на акушерската грижа се определя от професионалната преценка на акушерката;

- за да се грижат ефективно за жените, акушерките трябва да могат да ги насочат към съответните професионалисти / агенции - ОЗД, КСУДС, ДСП;

- потребностите на жените и техните семейства трябва да бъдат идентифицирани;

- индивидуализиране на акушерските грижи; алност;

- създаване на атмосфера на доверие и конфиденци-

• осигуряване на продължаващи акушерски грижи при постьпване за раждане и в постнаталния период;

- осыществяване на домашен патронаж в пренаталния и постнаталния период.

\section{Алгоритьм за осигуряване на \\ продължителна акушерска грижа}

Постигането на възможно най-добрите физически, емоционални и психологически резултати за жената и нейното бебе изисква Модел на грижа, при който здравната система дава възможност на всички жени да получат достъп до продължителни акушерски грижи, различни по интензивност и съобразени с индивидуалните потребности.

За да изпълни своята мисия задачите, които изпълнява продължителната акушерска грижа трябва да бъдат навременни, последователни и индивидуални. (Фигура 6)

Фигура 6. Алгоритъм за осигуряване на продължителната акушерска грижа

Регистрация и изготвяне на електронно досие
на бременната




\section{Основни целеви групи}

Целевата група включва бременни, родилки, новородени и техните семейства през пренаталния, антенаталния и постнаталния период.

Услугите са достъпни за всички, но техният обхват и интензивност са съобразени с индивидуалните потребности на всяка жена и семейство.

Фигура 7. Целеви групи

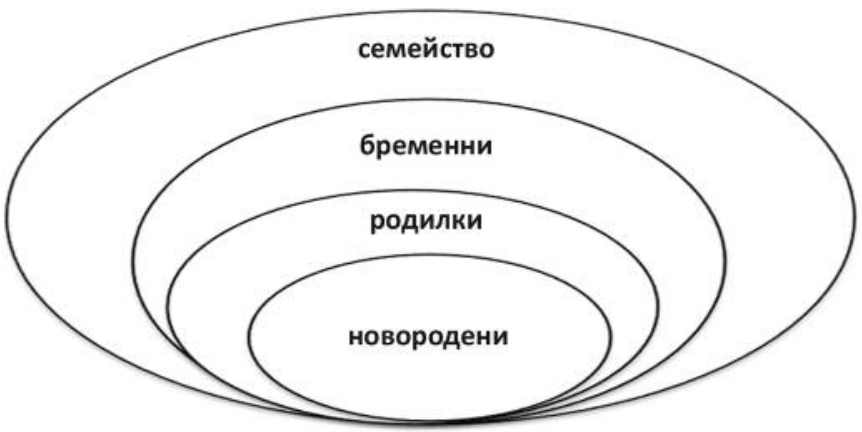

Приоритет са уязвимите групи:

- здравно-неосигурени бременни;

- семейства с деца, отглеждани при лоши материални и битови условия;

- семейства с деца, родени с ниско тегло, увреждания или хронични заболяване;

- родители с поведенчески проблеми или рисково поведение;

- приемни семейства или майки, настанени в социални институции поради риск от изоставяне на детето;

- затруднен достъп до здравеопазване поради финансови бариери, отдалеченост;

- бременни и майки с депресия и тревожност;

- деца в риск от насилие и изоставяне;

- майки и бременни под 18 г.;

- родители с ниско образование или увреждане, което е свързано със затруднения в полагането на грижи за децата.

\section{Изводи}

Осъществяването на продължителната акушерска грижа ще даде възможности и перспективи на акушерките, свързани с:
> насърчаване на безопасното майчинство чрез непрекъснатост на грижите в зависимост от потребностите на жените и обстановката, в която се полагат грижи;

- координиране на грижите за жените;

- разработване на кариерна рамка, която дава възможност на акушерките да придобият необходимия опит за напредване в кариерата си на клинично, управленско, изследователско и академично ниво;

- разработване на Стандарт от безопасни, висококачествени акушерски грижи.

Прилагането на модела за продължителна грижа ще бъде предизвикателство пред традиционните подходи и изисква съществена промяна в ресурсите на обществените услуги за предоставяне на грижи, които следват жената и семейството.

\section{Библиография}

1. Директива 2005/36/ на Европейския парламент и на Съвета на Европа от 7.9.2005 г. относно признаването на професионалните квалификации. OB L 255, 30.9.2005 г., с. 22. http://eur-lex.europa.eu/legal-content.

2. Доклад „Регулацията и организацията на акушерската дейност в БГ анализ на бариерите пред спазването на правата на жените Алианс на българските акушерки“, проект „Стратегия за дългосрочна застъпническа кампания за спазване на човешките и гражданските права в майчиното здравеопазване“" по Програма за подкрепа на НПО по ФМ на ЕИП 2009-2014

3. Наредба № 1 от 8 февруари 2011 г. за професионалните дейности, които медицинските сестри, акушерките, асоциираните медицински специалисти и здравните асистенти могат да извършват по назначение или самостоятелно.

4. Национална стратегия за демографско развитие на населението в Република България (2012-2020.)

5. Наредба за единните държавни изисквания за придобиване на висше образование по специалностите „медицинска сестра“, ,акушерка“ и „лекарски асистент“ за образователно-квалификационна степен „бакалавър“, обн. ДВ., бр.95 от 29 ноември 2005 г., загл. изм. и доп. ДВ, бр. 32 от 2016 г.

6. Тончева, С. и др. Нагласи и готовност на акушерките да изпълняват автономна дейност. // Здравни грижи, 2012, №1, с. 9-16.

7. Тончева, С., Евтимова, Т. Акушерски център за семейно консултиране - иновативен модел за семейно-консултативна дейност сред маргинални групи, Първа конференция с международно участие „Здравните грижи - принос за качество на живот“ 29-30.09.2016г., Варна

8. Midwifery 2020: Programme Core Role of the Midwife Workstream Final Report; 31 March 2010

9. National Institute for Health and Care Excellence. Intrapartum Care. Care of Healthy Women and their Babies During Childbirth. (Vol. 190). London: NICE; (2014).

\section{Автор}

Доц. Теодора Евтимова, катедра „Здравни грижи“, Филиал Шумен, МУ-Варна

\section{Още за д-р Стамен Григоров}

През 1905 г. Стамен Григоров се завръща от Трън в Женева, за да завърши последната си, четвърта година от медицинското си образование. В багажа му грижовно е вместена стомничка с подквасено мляко, наричана от трънчани „рукатка“. Стомничката удивлява приятелите му в студентската квартира, но професор Масол без обяснения веднага разбира намеренията на любимия си ученик. Оставя го да работи в лабораторията дни и нощи над микроскопа. Стамен Григоров поддържа и съхранява донесената подкваса, грижи се за нея като за незаменима скъпоценност. След може би хиляди опити над обектива той улавя „една пръчица“. Всъщност това е причинителят на българското кисело мляко. Впоследствие този „млечнокисел бацил“единодушно е назван от известните тогава учени Коенди, Микелсон, Люерсен и Коен „Lactobacterium bulgaricum”. Тогава Стамен Григоров е само на 27 години.

... Около средата на 30-те години определени среди от българските лекарски кръгове публично поставят под съмнение както откритието на млечнокиселия бактерий, така и резултатите от изследванията на лечебния ефект на пеницилиновите гъбички. Срамно звучи, че се намират лекари, които пишат до Медицинския факултет в Женева и питат дали е вярно, че българинът Стамен Григоров като стодент в този факултет през 1905 г. е открил „ферментите на българското кисело мляко“. С чисто швейцарска точност потомците на професор Масол отговарят „Да! Откритието е на българина Стамен Григоров. Съхранени са документи за тържеството, посветено на откривателя и за паричната награда, която му е била присъдена“. 